\title{
Characterization of two novel saccharolytic, anaerobic thermophiles, Thermoanaerobacterium polysaccharolyticum sp. nov. and Thermoanaerobacterium zeae sp. nov., and emendation of the genus Thermoanaerobacterium
}

\author{
Isaac K. O. Cann,† Peter G. Stroot, $\ddagger$ Kevin R. Mackie, Bryan A. White \\ and Roderick I. Mackie
}

Author for correspondence: Roderick I. Mackie. Tel: +1 217244 2526. Fax: + 12173338809 . e-mail: r-mackie@uiuc.edu

Department of Animal Sciences, 132 Animal Sciences Laboratory, 1207 W. Gregory Drive, University of Illinois at Urbana-Champaign, Urbana, IL 61801, USA
Two anaerobic, thermophilic, Gram-positive, non-spore forming bacteria with an array of polysaccharide-degrading enzymes were isolated from the leachate of a waste pile from a canning factory in Hoopeston, East Central Illinois, USA. The results of 165 rDNA sequence homology indicated that their closest relatives belong to the saccharolytic, thermophilic and anaerobic genera of Thermoanaerobacterium and Thermoanaerobacter. Although, the evolutionary distances between these bacteria and their closest relatives are greater than $11 \%$, there is no defining phenotypic characteristic for the creation of a new genus. It is proposed that these bacteria should be placed in the genus Thermoanaerobacterium, which requires emendment of the genus description with regard to the reduction of thiosulfate to sulfur, because neither isolate is capable of this reduction. Thermoanaerobacterium polysaccharolyticum reduces thiosulfate to sulfide, whereas Thermoanaerobacterium zeae is unable to reduce thiosulfate. The cells of both isolates are rod-shaped and exist as single cells or sometimes in pairs. Cells are motile by means of flagella. Growth occurs between 45 and $72{ }^{\circ} \mathrm{C}$, with optimum temperature of $65-68{ }^{\circ} \mathrm{C}$ at pH 6.8. The $\mathrm{pH}$ range for growth is from 4 to 8 at a temperature of $65^{\circ} \mathrm{C}$. Both organisms ferment glucose, arabinose, maltose, mannose, rhamnose, sucrose, trehalose, xylose, cellobiose, raffinose, melibiose and melezitose. The major end products of fermentation with glucose are ethanol and $\mathrm{CO}_{2}$, with lesser amounts of acetate, formate, lactate and hydrogen. The DNA G+C contents of Thermoanaerobacterium polysaccharolyticum sp. nov. and Thermoanaerobacterium zeae sp. nov. are 46 and $42 \mathrm{~mol} \%$, respectively. The type strains are KMTHCJ $\left(=\right.$ ATCC BAA-17 $^{\top}=$ DSM $\left.13641^{\top}\right)$ and mel2 $^{\top}\left(=\right.$ ATCC $^{\top}$ BAA-16 $^{\mathrm{T}}=$ DSM $\left.13642^{\mathrm{T}}\right)$, respectively.

Keywords: thermophilic, bacteria, Thermoanaerobacterium, Thermoanaerobacterium polysaccharolyticum, Thermoanaerobacterium zeae

\section{INTRODUCTION}

The importance of thermostable biomolecules in the growing field of biotechnology has spurred research into organisms capable of growth at high temperatures. During the last two decades, many reports have described the isolation of novel thermophilic organisms from both the domains Archaea and Bacteria

† Present address: New England Biolabs Inc., 32 Tozer Road, Beverly, MA 01915-5510, USA.

¥Present address: Department of Agricultural Engineering, University of Illinois at Urbana-Champaign, Urbana, IL 61801, USA.

The GenBank accession numbers for the 16S rDNA sequence of strains KMTHCJ ${ }^{\top}$ and mel2 ${ }^{\top}$ are U40229 and U75993, respectively. 
(Cayol et al., 1995; Cook et al., 1996; Engle et al., 1995, 1996; Fiala \& Stetter, 1986; Freier et al., 1988; Jones et al., 1983; Liu et al., 1996b; Schink \& Zeikus, 1983; Wiegel \& Ljungdahl, 1981). Most of the saccharolytic, anaerobic thermophiles belonging to the bacterial domain have received attention for their potential in the bioconversion of substrates of plant origin to end products such as lactate and ethanol, compounds with potential for the production of bulk chemicals and fuels (Lee et al., 1993b).

Members of the genera Thermoanaerobacterium and Thermoanaerobacter have been isolated from unique areas such as deep surface oil wells (Cayol et al., 1995), geothermally heated water outlets (Cook et al., 1996) and hot springs (Wiegel \& Ljungdahl, 1981). Several thermostable enzymes have either been purified or cloned from the members of this group of organisms. For example, polysaccharide-hydrolysing enzymes from this group are thermostable endoxylanases (Lee et al., 1993a; Liu et al., 1996a) which can be used in biomass conversion and the pulp and paper industry.

Several thermophilic bacteria have recently been isolated from the leachate of a waste pile from a canning factory in Illinois, USA. In this paper, two unique, non-spore-forming, Gram-positive Thermoanaerobacterium members capable of using a wide range of carbohydrate sources for the heterofermentative production of lactate or ethanol are described. A recent publication describes the cloning and sequencing of a thermostable multidomain mannanase from one of the novel isolates (Cann et al., 1999).

\section{METHODS}

Sample site. A canning factory situated in Hoopeston, Illinois, USA, which seasonally processes sweet corn and other vegetables, was selected for study. Organic waste from the canning process is dumped 1 mile west of town. The waste pile and surrounding run-off were characterized by active gas evolution, low $\mathrm{pH}(5 \cdot 5)$, high concentrations of short-chain fatty acids $(31.6 \mathrm{mM}$ acetate, $8.2 \mathrm{mM}$ propionate, $26.0 \mathrm{mM}$ butyrate and $6.4 \mathrm{mM}$ valerate) as well as heat generation. Temperature was not recorded, but exhibited a steep gradient away from the centre of the waste pile. A subsurface sample of the leachate from this waste pile was collected in screw-cap flasks and transported under anaerobic conditions and ambient temperature to the laboratory. The sample was kept at $4{ }^{\circ} \mathrm{C}$ until used to inoculate enrichment medium.

Enrichments. To isolate strain $\mathrm{KMTHCJ}^{\mathrm{T}}$, aliquots $(0.2 \mathrm{ml})$ of samples were inoculated into a volume of a minimal medium containing raffinose as sole added carbon and energy source $\left[0.25 \mathrm{~g}\right.$ Trypticase-peptone $\mathrm{l}^{-1}$ (BBL Microbiology Systems), $5 \mathrm{~g}$ raffinose $1^{-1}, 50 \mathrm{ml}$ Pfennig's mineral solution $\left(\mathrm{g} \mathrm{l}^{-1}: \mathrm{KH}_{2} \mathrm{PO}_{4}, 10 ; \mathrm{MgCl}_{2} .6 \mathrm{H}_{2} \mathrm{O}, 6 \cdot 6 ; \mathrm{NaCl}, 8 \cdot 0\right.$; $\left.\mathrm{NH}_{4} \mathrm{Cl}, 8 \cdot 0 ; \mathrm{CaCl}_{2} .2 \mathrm{H}_{2} \mathrm{O}, 1 \cdot 0\right), 1 \mathrm{ml}$ Pfennig's trace elements solution $\left(\mathrm{g}^{-1}: \mathrm{ZnSO}_{4} \cdot 7 \mathrm{H}_{2} \mathrm{O}, 0 \cdot 1 ; \mathrm{MnCl}_{2} \cdot 4 \mathrm{H}_{2} \mathrm{O}\right.$, $0.03 ; \mathrm{H}_{3} \mathrm{BO}_{3}, 0 \cdot 3 ; \mathrm{CoCl}_{2} \cdot 6 \mathrm{H}_{2} \mathrm{O}, 0 \cdot 2 ; \mathrm{CuCl}_{2} .2 \mathrm{H}_{2} \mathrm{O}, 0 \cdot 01$; $\mathrm{NiCl}_{2} .6 \mathrm{H}_{2} \mathrm{O}, 0 \cdot 02 ; \mathrm{Na}_{2} \mathrm{MoO}_{4} .2 \mathrm{H}_{2} \mathrm{O}, 0 \cdot 03 ; \mathrm{FeCl}_{2} .4 \mathrm{H}_{2} \mathrm{O}$, $\left.1 \cdot 5 ; \mathrm{Na}_{2} \mathrm{SeO}_{3}, 0 \cdot 01\right)$ and $1 \mathrm{ml} 0 \cdot 1 \%(\mathrm{w} / \mathrm{v})$ resazurin]. The medium was prepared under anaerobic conditions using the following procedure. The medium was boiled in a microwave oven and cooled under a stream of oxygen-free carbon dioxide prepared by passage through a column of heated copper filings. This was then dispensed in $9.0 \mathrm{ml}$ amounts into $15 \times 180 \mathrm{~mm}$ Balch tubes in an anaerobic chamber (Coy Laboratory Products). Dispensed medium was autoclaved for $15 \mathrm{~min}$ at $110^{\circ} \mathrm{C}$. After cooling, $0.2 \mathrm{ml} 1.25 \%$ cysteine $\mathrm{HCl} / \mathrm{Na}_{2} \mathrm{~S}$ (sterile), $0.05 \mathrm{ml} \mathrm{B}$ vitamin solution $(0.2 \mathrm{~g}$ thiamin $\mathrm{HCl}, 0.2 \mathrm{~g}$ calcium D-pantothenate, $0.2 \mathrm{~g}$ riboflavin, $0.2 \mathrm{~g}$ pyridoxine $\mathrm{HCl}, 0.01 \mathrm{~g} p$-amino benzoic acid, $0.25 \mathrm{~g}$ biotin, $0.25 \mathrm{~g}$ folic acid and $0.01 \mathrm{~g}$ vitamin $\mathrm{B}_{12}$ ) and $0.7 \mathrm{ml} 7 \%(\mathrm{w} / \mathrm{v}) \mathrm{NaHCO}_{3}$ (filter-sterilized) were injected into each tube. The initial samples were incubated at $60{ }^{\circ} \mathrm{C}$ until visible growth was observed and passed through a series of serial dilutions until a uniformly pure culture was obtained, as determined by microscopic examination of wet mounts and Gram-stained preparations.

Strain mel2 $2^{\mathrm{T}}$ was isolated using the enrichment procedure described for strain KMTHCJ ${ }^{\mathrm{T}}$, except that melibiose was the carbon and energy source. Aliquots from tubes showing growth were streaked on plates of the same defined medium. A colony was picked and grown in the defined medium based on melibiose and passed through several serial dilutions until a uniformly pure culture was obtained.

Physiological properties. The isolates were grown on representative carbon sources (glucose, arabinose, lactose, maltose, rhamnose, sucrose, trehalose, xylose, cellobiose, mannose, raffinose, sorbose, melibiose, melezitose, pyruvate, mannitol, fumarate, malate or citrate) to determine whether different substrates could be used as sole carbon source. Bacterial growth was monitored by determining the $\mathrm{OD}_{600}$ (Spectronic 70; Bausch and Lomb). In addition, ability to grow on cracked corn, ground corn cob and ground corn stalk was evaluated. The carbon sources were suspended separately under anaerobic conditions in distilled water and sterilized by autoclaving. They were then added to sterile defined medium to a final concentration of $0.5 \%(\mathrm{w} / \mathrm{v})$. Nitrate reduction, catalase and indole production tests were carried out as described by Smibert \& Krieg (1994). The defined medium described above with glucose as energy source was used to grow both bacteria above $37^{\circ} \mathrm{C}$ to determine their respective optimum temperatures for growth. In the optimum $\mathrm{pH}$ studies, the isolates were grown at $68{ }^{\circ} \mathrm{C}$ in the defined medium with glucose as the carbon source and the initial $\mathrm{pH}$ adjusted over the ranges $5 \cdot 0-8 \cdot 0$ for strain $\mathrm{KMTHCJ}^{\mathrm{T}}$ and 1.0-9.0 for strain mel $2^{\mathrm{T}}$. The reduction of thiosulfate, sulfate and sulfur at a $20 \mathrm{mM}$ concentration was tested. Excess iron $(0.5 \mathrm{mM})$ in the form of $\mathrm{FeCl}_{2} \cdot 4 \mathrm{H}_{2} \mathrm{O}$ was added to the Balch tubes in order to detect sulfide precipitation. At our incubation temperature, it was necessary to use a low cysteine $\mathrm{HCl}$ concentration of $0.05 \%$ $(\mathrm{w} / \mathrm{v})$, in order to prevent precipitation of the excess iron with the breakdown of the cysteine. $\mathrm{HCl}$. Microscopic examination was used to check for sulfur formation. Reductive acetogenesis was examined by including $80 \% \mathrm{H}_{2}$ and $20 \% \mathrm{CO}_{2}$ in the headspace above the basal medium without glucose and measuring the change in $\mathrm{OD}_{600}$ compared to the basal medium.

Morphological characteristics. Routine examination for purity was carried out using an Olympus BH-2 microscope. Gram staining was performed according to the method of Huckner (Murray et al., 1994) and compared to positive controls stained on the same slide. Morphology was examined by phase-contrast microscopy, TEM and negative staining. For TEM, cells were immersed in a modified Karnovsky's fixative overnight and treated with a solution 
of $1 \%(\mathrm{w} / \mathrm{v})$ osmium tetroxide. The sample was dehydrated and a solution of $100 \%(\mathrm{v} / \mathrm{v})$ ethanol and propylene oxide in the ratio 1:1 was finally used to rinse the sample. Embedding was with Epon 812 epoxy resin. The thin sections that were generated were placed on a grid for EM (JEOL 100C at $80 \mathrm{kV}$ ). For negative staining, a carbon-coated Formvar grid was suspended on a drop of specimen. This was then placed on a drop of $2 \%(\mathrm{w} / \mathrm{v})$ ammonium molybdate $(\mathrm{pH}$ 6.2) and dried for $20 \mathrm{~min}$, after which it was observed by EM.

Analytical methods. Gas composition was analysed using a GC (Gow-Mac Series 580) with an Alltech column $\left(30^{\prime} \times 1 / 8^{\prime \prime} \times 0 \cdot 085^{\prime \prime}\right.$ SS packed with GAS CHROM MP-1 $100 / 120 \mathrm{mesh})$ and a thermal conductivity detector. The

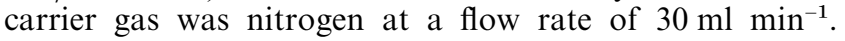
Solvents produced were determined and quantified with a GC (model 5710A Hewlett Packard) on an 80/100 Carbopack C/0 $1 \%$ SP-1000 column of size $6^{\prime} \times 1 / 8^{\prime \prime} \mathrm{SS}$. The carrier gas was nitrogen at a flow rate of $20 \mathrm{ml} \mathrm{min}$. The oven, flame-ionization detector and injection temperatures were 120,200 and $200{ }^{\circ} \mathrm{C}$, respectively. Volatile fatty acids were determined by GC (model 5890A Hewlett Packard) on a glass column $(180 \mathrm{~cm} \times 4 \mathrm{~mm}$ i.d. $)$ packed with GP $10 \% \mathrm{SP}-1200 / 1 \% \mathrm{H}_{3} \mathrm{PO}_{4}$ on $80 / 100$ Chromasorb WAW (Supelco). The carrier gas was nitrogen at a flow rate of $75 \mathrm{ml} \mathrm{min}{ }^{-1}$. The oven, detector and injection temperatures were 125,180 and $175^{\circ} \mathrm{C}$, respectively. Formate and lactate were determined by HPLC using an ion exclusion Bio-Rad Aminex HPX-87H column. The eluent was 0.0025

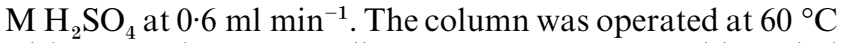
with a UV detector reading at $210 \mathrm{~nm}$. Fatty acid methyl ester analysis was performed by Microchek. This analysis consisted of a GC with a $5 \%$ methyl phenyl silicone capillary column and flame-ionization detector.

PCR amplification of 16S rDNA. Approximately $200 \mathrm{ng}$ genomic DNA was used in a $50 \mu \mathrm{l}$ PCR mixture. The reaction mixture contained $250 \mathrm{mM}$ of each dNTP, $50 \mathrm{mM}$ $\mathrm{KCl}, 2 \mathrm{mM} \mathrm{MgCl}_{2}$ and other ingredients as described by the manufacturer (LA PCR kit; Takara Shuzo). The primers used were $008 \mathrm{~F}$ and $1517 \mathrm{R}$ and were each at a concentration of $1 \cdot 1 \mu \mathrm{M}$. PCR involved 29 cycles of denaturation at $94{ }^{\circ} \mathrm{C}$ for $30 \mathrm{~s}$, annealing at $45^{\circ} \mathrm{C}$ for $1 \mathrm{~min}$ and extension at $72^{\circ} \mathrm{C}$ for $3.5 \mathrm{~min}$. An aliquot of amplified DNA fragment was analysed by electrophoresis on a $0.9 \%$ agarose gel, stained with ethidium bromide and examined under UV light.

Cloning and sequencing. The $1.4 \mathrm{~kb}$ fragment obtained was cloned by directly ligating the fragment into a pGEM-T vector DNA (Promega) and the product was used to transform Escherichia coli $\mathrm{DH} 5 \alpha$ by electroporation. The $E$. coli cells with recombinant plasmids were selected on Luria-Bertani plates incorporating $\mathrm{X}-\mathrm{Gal}$ and IPTG. Plasmids were extracted according to the method of Birnboim \& Doly (1979) and purified by using Qiagen columns. An ABI automated DNA sequencer (Applied Biosystems) was used for sequencing the entire DNA insert in both directions to confirm the integrity of the sequence obtained.

16S rRNA sequence analysis. Species used for the analysis (with gene accession numbers in parentheses) are as follows: E. coli (AE000460); Moorella thermoacetica (M59121); Moorella thermoautotrophica (L09168); Thermoanaerobacter thermocopriae (L09167); Thermoanaerobacter ethanolicus (L09164); Thermoanaerobacter brockii (L09165); Thermoanaerobacter finnii (L09166); Thermoanaerobacter kivui (L09160); Thermoanaerobacter thermohydrosulfuricus (L09161); Thermoanaerobacter acetoethylicus (L09163); Thermoanaerobacter wiegelii (X92513); Thermoanaerobacterium xylanolyticum (L09172); Thermoanaerobacterium aotearoense (X93359); Thermoanaerobacterium saccharolyticum (L09169); 'Thermoanaerobium lactoethylicum' (L09170); and Thermoanaerobacterium thermosulfurigenes (L09171). Using the program CLUSTAL $\mathrm{v}$ (Higgins et al., 1991), the 16S rDNA sequences obtained were aligned. Regions showing alignment uncertainties and gaps were excluded from the alignments and 1238 unambiguous nucleotide positions were used in computing evolutionary distances by the method of Jukes \& Cantor (1969). The evolutionary distance matrix was used in constructing a dendrogram using the neighbourjoining method (NEIGHBOR). The programs used for the phylogenetic analysis can all be found in the PHYLIP package (Felsenstein, 1995).

DNA base composition. The $\mathrm{G}+\mathrm{C}$ content of the DNA was determined according to the method described by Marmur \& Doty (1962). Genomic DNA from Butyrivibrio fibrisolvens strain 49 (University of Illinois, Department of Animal Sciences Culture Collection), Micrococcus luteus ATCC $4698^{\mathrm{T}}$ and Clostridium perfringens strain 14115-15 (USDAARS), with $\mathrm{G}+\mathrm{C}$ contents of $41,70 \cdot 0-75 \cdot 5$ and $24-27$ mol \%, respectively, were used as references. Genomic DNA from Butyrivibrio fibrisolvens strain 49 was used for melting temperature $\left(T_{\mathrm{m}}\right)$ calculations. Analysis was performed on a Beckman model DU-640 Spectrophotometer equipped with a $T_{\mathrm{m}}$ analysis accessory.

\section{RESULTS AND DISCUSSION}

\section{Morphology}

The cells of strain $\mathrm{KMTHCJ}^{\mathrm{T}}$ and strain $\mathrm{mel} \mathrm{2}^{\mathrm{T}}$ occurred as straight rods, singly or in pairs (Fig. 1). Chain formation was observed on rare occasions. The cells were motile as observed under light microscopy. Strain KMTHCJ ${ }^{\mathrm{T}}$ exhibited a tumbling motility and flagella could be observed (Fig. 1a). Strain mel2 $2^{\mathrm{T}}$ was actively motile through flagella which were peritrichously arranged (Fig. 1b). The cells stained Gram-variable. Thin sections of both species showed a Gram-positive ultrastructure under EM (Fig. 1c, d). Both genera Thermoanaerobacter and Thermoanaerobacterium have members that stain Gram-positive and -negative (Cayol et al., 1995; Cook et al., 1996; Liu et al., 1996b). Differences in Gram staining and other characteristics between the two new strains and the type species of Thermoanaerobacter and Thermoanaerobacterium are listed in Table 1. These bacteria are likely to exhibit a surface-layer protein (see Fig. 2) as in related organisms (Liu et al., 1996a; Brechtel \& Bahl, 1999), which is supported by the presence of an S-layer-like protein region observed at the $\mathrm{C}$-terminal region of a mannanase gene that has been cloned and sequenced from strain $\mathrm{KMTHCJ}^{\mathrm{T}}$ (Cann et al., 1999). Strain mel2 $2^{\mathrm{T}}$ grew readily on agar surfaces, whereas strain $\mathrm{KMTHCJ}^{\mathrm{T}}$ did not grow readily on nutrient agar plates, but could be maintained on agar slants. Spore formation has been observed within the genera Thermoanaerobacterium 

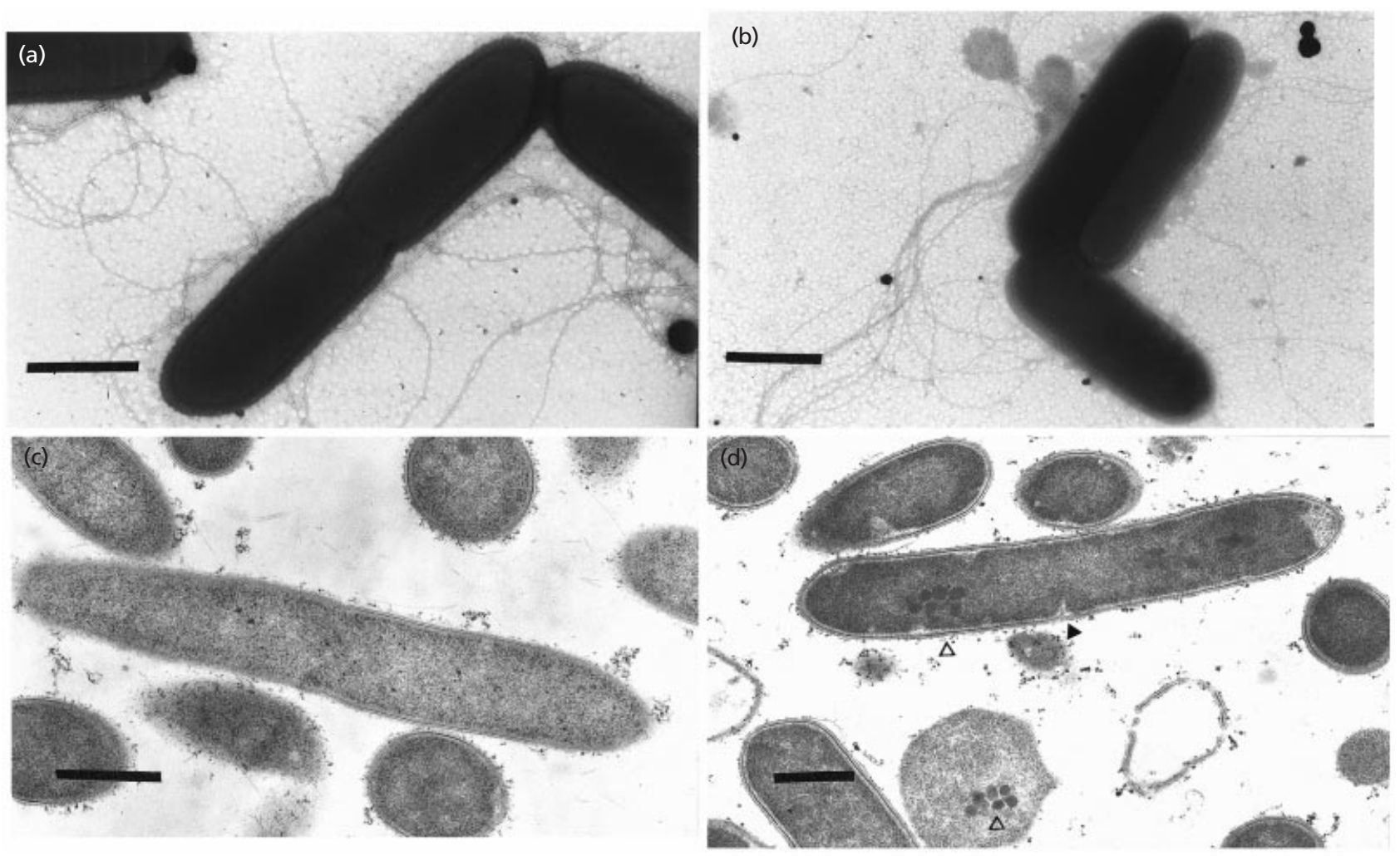

Fig. 1. TEM of negatively stained cells $(a, b)$ and ultrathin sections $(c, d)$ of Thermoanaerobacterium polysaccharolyticum $(a, c)$ and Thermoanaerobacterium zeae $(b, d)$ grown on minimal medium containing $0.5 \%$ glucose at $65{ }^{\circ} \mathrm{C}$. Intracellular granules $(\triangle)$ and invagination of the cytoplasmic membrane prior to cell division $(\boldsymbol{\Delta})$ in Thermoanaerobacterium zeae are marked (d). Bars: $a$ and b, $1 \mu \mathrm{m} ; \mathrm{c}$ and $d, 0.5 \mu \mathrm{m}$.

and Thermoanaerobacter (Cayol et al., 1995; Cook et al., 1996; Liu et al., 1996b); however, this characteristic was not observed with either strain under the conditions of growth investigated. According to Cato \& Stackebrandt (1989), spore formation is not an effective taxonomic characteristic and the variation in this characteristic between members of the genera Thermoanaerobacterium and Thermoanaerobacter provides further evidence to support this. Cell division appeared to occur through a septation mechanism as described for Thermoanaerobacter wiegelii (Cook et al., 1996). The major fatty acids (Table 2) were determined to be iso $15: 0$ (70.6 and $61.6 \%$ in strains $\mathrm{KMTHCJ}^{\mathrm{T}}$ and mel2 ${ }^{\mathrm{T}}$, respectively) and iso 17:0 (19.2 and $26.8 \%$ in strains $\mathrm{KMTHCJ}^{\mathrm{T}}$ and mel2 ${ }^{\mathrm{T}}$, respectively). The only other fatty acid detected was straight chain 16:0 (10.1 and 9.4\% in strains KMTHCJ ${ }^{\mathrm{T}}$ and mel2 $2^{\mathrm{T}}$, respectively). These results are remarkably similar to those reported for Thermoanaerobacter thermohydrosulfuricus, Thermoanaerobacter thermocopriae and Thermoanaerobacterium thermosulfurigenes by Yamamoto et al. (1998). Thermoanaerobacterium thermosaccharolyticum differed from the other five strains reported in Table 2 by having high levels of 14:0 straight chain $(32.5 \%)$ and an elevated level of $16: 0$ straight chain $(25.5 \%)$ fatty acids. Although reasonably consistent, the cellular fatty acid profiles do not provide a basis for differentiating Thermoanaerobacter from Thermoanaerobacterium or for reliably differentiating between the five strains reported in the Table.

\section{Growth and physiology}

Strain KMTHCJ ${ }^{\mathrm{T}}$ and strain mel $2^{\mathrm{T}}$ did not require yeast extract for growth. This is unlike most members of the genera Thermoanaerobacter (Cayol et al., 1995; Cook et al., 1996; Wiegel \& Ljungdahl, 1981) and Thermoanaerobacterium (Lee et al., 1993b). In the presence of oxygen in the headspace, characterized by the pink colour of resazurin (oxidized medium), growth occurred with subsequent reduction of resazurin (colourless). However, both isolates would only grow in the anaerobic region of a stab culture. Thus, both isolates are obligate anaerobic bacteria that exhibit aerotolerance. This is similar to the members of the genera Thermoanaerobacter (Cayol et al., 1995; Cook et al., 1996) and Thermoanaerobacterium (Liu et al., 1996b), which require anoxic conditions for growth. Strain KMTHCJ ${ }^{\mathrm{T}}$ grows between 45 and $70{ }^{\circ} \mathrm{C}$, with the optimum temperature for growth on glucose occurring between 
Table 1 Characteristics that differentiate strains $\mathrm{KMTHCJ}^{\top}$ and $\mathrm{mel}^{\top}$ from other phylogenetically related thermophilic bacteria

+ , Positive; -, negative; ND, not determined.

\begin{tabular}{|c|c|c|c|c|}
\hline Character & Strain KMTHCJ ${ }^{\mathrm{T}}$ & Strain mel2 $2^{\mathrm{T}}$ & $\begin{array}{c}\text { Thermoanaerobacterium } \\
\text { thermosulfurigenes } \\
\text { strain } 4 \mathrm{~B}^{\mathrm{T} *}\end{array}$ & $\begin{array}{c}\text { Thermoanaerobacter } \\
\text { ethanolicus strain } \\
\text { JW200 }^{\mathrm{T}} \dagger\end{array}$ \\
\hline Gram stain & Variable & Variable & Negative & Variable \\
\hline $\mathrm{G}+\mathrm{C}$ content $(\mathrm{mol} \%)$ & 46 & 42 & $32 \cdot 6$ & 32 \\
\hline Spore formation & - & - & + & - \\
\hline $\mathrm{pH}$ range & $5 \cdot 0-8 \cdot 0$ & $3 \cdot 9-7 \cdot 9$ & $4 \cdot 0-7 \cdot 5$ & $4 \cdot 4-9 \cdot 8$ \\
\hline Optimum $\mathrm{pH}$ & $6 \cdot 8-7 \cdot 0$ & $\mathrm{ND}$ & $5 \cdot 5-6 \cdot 5$ & $5 \cdot 8-8 \cdot 5$ \\
\hline Optimum temp. $\left({ }^{\circ} \mathrm{C}\right)$ & $65-68$ & $65-70$ & $\geqslant 60$ & 69 \\
\hline Max. temp. $\left({ }^{\circ} \mathrm{C}\right)$ & 70 & 72 & 75 & 78 \\
\hline Formate produced & + & + & - & - \\
\hline \multicolumn{5}{|l|}{ Utilization of: } \\
\hline Cracked corn & - & + & ND & ND \\
\hline Starch & - & + & + & + \\
\hline Xylan & - & + & - & + \\
\hline Melibiose & + & + & + & - \\
\hline Melizitose & + & + & - & - \\
\hline Mannose & + & + & $\mathrm{ND}$ & + \\
\hline Arabinose & + & + & + & ND \\
\hline Rhamnose & + & + & + & - \\
\hline Raffinose & + & + & - & - \\
\hline Lactose & + & + & - & + \\
\hline Sorbose & - & - & ND & ND \\
\hline Fructose & + & + & $\mathrm{ND}$ & + \\
\hline Mannitol & - & - & + & - \\
\hline Malate & - & - & $\mathrm{ND}$ & $\mathrm{ND}$ \\
\hline Fumarate & - & - & ND & ND \\
\hline Citrate & - & - & $\mathrm{ND}$ & ND \\
\hline Trehalose & + & + & + & - \\
\hline Salicin & + & + & + & $\mathrm{ND}$ \\
\hline Pyruvate & + & + & - & + \\
\hline Pectin & - & - & + & ND \\
\hline $\mathrm{H}_{2} / \mathrm{CO}_{2}$ & - & - & - & ND \\
\hline
\end{tabular}

* Data from Schink \& Zeikus (1983).

$\dagger$ Data from Wiegel \& Ljungdahl (1981).

65 and $68^{\circ} \mathrm{C}$ at $\mathrm{pH} 6 \cdot 8$. Thermoanaerobacter wiegelii shows similar optimum temperature for growth (Cook et al., 1996). No growth was observed at 45 or $75^{\circ} \mathrm{C}$. Similarly, strain mel2 $2^{\mathrm{T}}$ grew between 55 and $72^{\circ} \mathrm{C}$, with the optimum temperature for growth on glucose occurring between 65 and $70{ }^{\circ} \mathrm{C}$ at $\mathrm{pH} 6 \cdot 8$. Growth was not observed above $72{ }^{\circ} \mathrm{C}$ or below $37^{\circ} \mathrm{C}$. The end products of glucose fermentation for both isolates included ethanol and carbon dioxide, with hydrogen, acetate, formate and lactate being produced in lesser amounts. Strain mel $2^{\mathrm{T}}$ produced more formate than acetate from glucose fermentation, whereas strain $\mathrm{KMTHCJ}^{\mathrm{T}}$ produced more acetate than formate. This fermentation is similar to that of other thermoanaerobes found in the domain Bacteria, although the high amounts of formate produced are unique (Lee et al., 1993b). The ability of Thermobrachium celere to produce formate was used to differentiate it from the genus Thermoanaerobacter (Engle et al., 1996). Although strains KMTHCJ ${ }^{\mathrm{T}}$ and $\mathrm{mel} 2^{\mathrm{T}}$ both produce formate, cell morphology and significant $16 \mathrm{~S}$ rDNA sequence differences exclude placement of the new strains in the genus Thermobrachium. Both organisms fermented a wide variety of complex and simple carbohydrates including melibiose, raffinose, arabinose, galactose, lactose, maltose, mannose, rhamnose, sucrose, trehalose, xylose, cellobiose and melezitose, whereas cellulose was not utilized. A modular enzyme has been cloned and sequenced from strain KMTHCJ ${ }^{\mathrm{T}}$ (Cann et al., 1999) and the presence of an enzyme with carboxymethylcellulase activity has been demonstrated in strain mel2 ${ }^{\mathrm{T}}$. When glucose and xylose were 


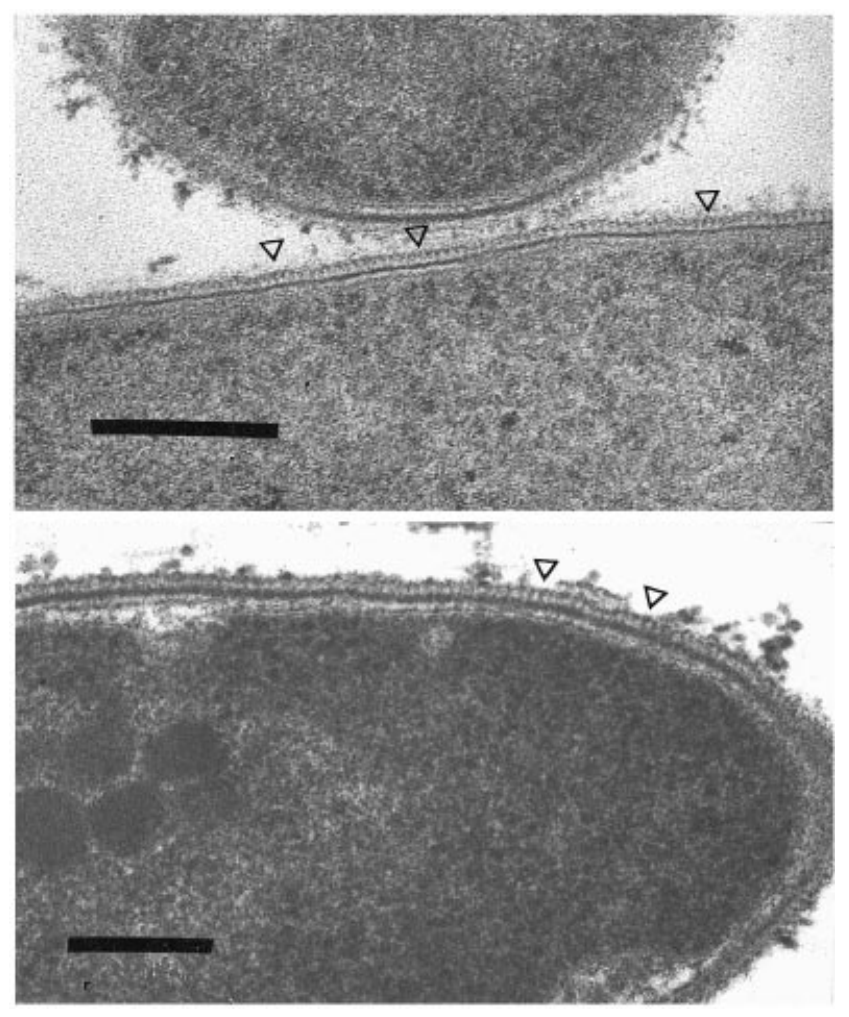

Fig. 2. Cell wall of Thermoanaerobacterium polysaccharolyticum (top) and Thermoanaerobacterium zeae (bottom) under high magnification of ultrathin sections, showing multilayered structure and cytoplasmic membrane characteristics of Gram-positive ultrastructure. The outer cell surface is covered by a regular array of repeating units $(\triangle)$ characteristic of bacterial cell surface or S-layer proteins. Bars, $0 \cdot 2 \mu \mathrm{m}$.

present in the medium in equal proportions, both substrates were used simultaneously by strain $\mathrm{KMTHCJ}^{\mathrm{T}}$ (data not shown). This lack of diauxic growth has been observed in both Thermoanaerobacter ethanolicus (Carreira et al., 1983) and Thermoanaerobacter wiegelii (Cook et al., 1996). Catalase activity was negative for both isolates, which is consistent with the genera Thermoanaerobacter (Cayol et al., 1995; Holt et al., 1994) and Thermoanaerobacterium (Holt et al., 1994; Lee et al., 1993b; Liu et al., 1996a). Neither isolate reduced nitrate or produced indole. Similar observations have been made for the genus Thermoanaerobacter (Holt et al., 1994). Of the Thermoanaerobacterium species, only Thermoanaerobacterium thermosulfurigenes has been described as not reducing nitrate, whereas other species have not been tested (Lee et al., 1993b; Liu et al., 1996b). The inability to produce indole has been reported only for Thermoanaerobacterium aotearoense (Lee et al., 1993b; Liu et al., 1996b). The doubling times were $2 \cdot 1,3 \cdot 4$ and $5.5 \mathrm{~h}$ at $68{ }^{\circ} \mathrm{C}$ with glucose, raffinose and melibiose as the carbon source in a minimal medium (described previously), respectively, for strain $\mathrm{KMTHCJ}^{\mathrm{T}}$. On the other hand, the doubling time was $1.8 \mathrm{~h}$ at $65-70{ }^{\circ} \mathrm{C}$ with glucose as the carbon source in a minimal medium for strain mel2 $2^{\mathrm{T}}$. Growth on cracked corn, starch and xylan in a minimal medium was only observed for strain mel2 $2^{\mathrm{T}}$. Both strains grew in an acidic to neutral $\mathrm{pH}$. The $\mathrm{pH}$ range for strain $\mathrm{KMTHCJ}^{\mathrm{T}}$ was between 5.0 and 8.0 , whereas strain mel2 $2^{\mathrm{T}}$ grew between $\mathrm{pH} 3.9$ and 7.9. The optimum $\mathrm{pH}$ range for strain KMTHCJ ${ }^{\mathrm{T}}$ was $6 \cdot 8-7 \cdot 0$ at a temperature of $65^{\circ} \mathrm{C}$. The ability to grow at low $\mathrm{pH}$ was expected, since the leachate from the waste pile from which these bacteria were isolated was acidic ( $\mathrm{pH}$ of 5.5) in nature.

Both isolates were tested for their ability to reduce sulfate, sulfur and thiosulfate $(20 \mathrm{mM})$. Neither organism reduced sulfate or sulfur. Strain KMTHCJ ${ }^{T}$ reduced thiosulfate to sulfide, but strain $\mathrm{mel} 2^{\mathrm{T}}$ did not reduce thiosulfate. The thiosulfate reduction assay has been proposed as a method for distinguishing between the genera Thermoanaerobacter (reduction of thio-

Table 2 Cellular fatty acid composition (\%) of species of Thermoanaerobacter and Thermoanaerobacterium and novel strains $\mathrm{KMTHCJ}^{\top}$ and $\mathrm{mel} 2^{\top}$

Abbreviations: ND, not detected; TR, trace amount $(<0.5 \%)$.

\begin{tabular}{|c|c|c|c|c|c|c|c|c|c|c|c|c|c|c|}
\hline \multirow[t]{3}{*}{ Type strain } & \multicolumn{11}{|c|}{ Saturated } & \multirow{2}{*}{\multicolumn{2}{|c|}{$\frac{\text { Unsaturated }}{\text { Straight chain }}$}} & \multirow[t]{3}{*}{ Growth temp. $\left({ }^{\circ} \mathrm{C}\right.$} \\
\hline & \multicolumn{5}{|c|}{ Straight chain } & \multicolumn{6}{|c|}{ iso-Branched chain } & & & \\
\hline & $14: 0$ & $15: 0$ & $16: 0$ & $17: 0$ & 18:0 & 13:0 & $14: 0$ & $15: 0$ & $16: 0$ & $17: 0$ & 18:0 & $16: 1$ & $18: 1$ & \\
\hline \multicolumn{15}{|l|}{ Genus Thermoanaerobacter } \\
\hline T. thermohydrosulfuricus DSM $567^{\mathrm{T}} \dagger$ & $0 \cdot 5$ & $7 \cdot 6$ & $11 \cdot 2$ & ND & $1 \cdot 2$ & ND & ND & $47 \cdot 3$ & $3 \cdot 1$ & $23 \cdot 3$ & $2 \cdot 1$ & ND & $3 \cdot 7$ & 60 \\
\hline T. thermocopriae IAM $13577^{\mathrm{T}} \uparrow$ & $\mathrm{TR}$ & $5 \cdot 0$ & $1 \cdot 1$ & $10 \cdot 3$ & 1.8 & TR & ND & $54 \cdot 1$ & 1.6 & $24 \cdot 7$ & $0 \cdot 5$ & ND & ND & 60 \\
\hline \multicolumn{15}{|l|}{ Genus Thermoanaerobacterium } \\
\hline T. thermosulfurigenes DSM $2229^{\mathrm{T}} \dagger$ & $\mathrm{TR}$ & $4 \cdot 1$ & $12 \cdot 7$ & $3 \cdot 6$ & $1 \cdot 2$ & TR & TR & $42 \cdot 4$ & $4 \cdot 6$ & $23 \cdot 3$ & $4 \cdot 0$ & ND & $2 \cdot 6$ & 60 \\
\hline T. thermosaccharolyticum DSM $571^{\mathrm{T}} \uparrow$ & $32 \cdot 5$ & ND & $25 \cdot 5$ & $\mathrm{TR}$ & 1.5 & ND & ND & $21 \cdot 6$ & ND & $16 \cdot 7$ & $1 \cdot 3$ & ND & $\mathrm{TR}$ & 60 \\
\hline \multicolumn{15}{|l|}{ Novel isolates } \\
\hline Strain $\mathrm{KMTHCJ}^{\mathrm{T}}$ & ND & ND & $10 \cdot 1$ & ND & ND & ND & ND & $70 \cdot 6$ & ND & $19 \cdot 2$ & ND & ND & ND & 65 \\
\hline Strain mel $2^{\mathrm{T}}$ & ND & ND & $9 \cdot 4$ & ND & ND & ND & ND & $61 \cdot 6$ & ND & $26 \cdot 8$ & ND & ND & ND & 65 \\
\hline
\end{tabular}

* Number of carbon atoms: number of double bonds.

$\dagger$ Data from Yamamoto et al. (1998). 
sulfate to sulfide) and Thermoanaerobacterium (reduction of thiosulfate to elemental sulfur) (Lee et al., 1993b). Based on these results, neither organism can be described as a member of the genus Thermoanaerobacterium and strain $\mathrm{KMTHCJ}^{\mathrm{T}}$ should be considered as a member of the genus Thermoanaerobacter based on this characteristic.

\section{DNA base composition}

The DNA G + C contents of strain $\mathrm{KMTHCJ}^{\mathrm{T}}$ and strain $\mathrm{mel}^{\mathrm{T}}$, as determined by the thermal denaturation method (Marmur \& Doty, 1962), were 46 and $42 \mathrm{~mol} \%$, respectively. These values are higher than those observed for the type species of the genera Thermoanaerobacter and Thermoanaerobacterium as shown in Table 1 (Schink \& Zeikus, 1983; Wiegel \& Ljungdahl, 1981). However, they are close to the $\mathrm{G}+\mathrm{C}$ content of $40 \mathrm{~mol} \%$ reported for Clostridium thermocellum JW20 (Freier et al., 1988). Similarity of the $\mathrm{G}+\mathrm{C}$ contents among members of polysaccharidedegrading bacteria belonging to the genera Clostridium, Thermoanaerobacterium and Thermoanaerobacter rendered it unfeasible to separate them into groups based on this criterion (Lee et al., 1993b).

\section{S rRNA gene sequence analysis}

Almost complete 16S rDNA sequences of strain KMTHCJ $^{\mathrm{T}}$ (1438 bases) and strain mel2 ${ }^{\mathrm{T}}$ (1449 bases) were PCR-amplified and cloned in E. coli DH5 $\alpha$. Using six primers, the $5^{\prime}$ and $3^{\prime}$ strands were sequenced. These sequences [positions 8-1517 of E. coli consensus numbering (Winker \& Woese, 1991)] were aligned to the fifteen most closely related sequences and phylogenetic analysis was performed. The sequence comparison revealed that both strain $\mathrm{KMTHCJ}^{\mathrm{T}}$ and strain mel2 ${ }^{\mathrm{T}}$ have no known close relatives among previously described bacteria. Their phylogenetic position is, however, within the large subgroup consisting of the low-G + C-content, Gram-positive bacteria (Bacillus/Clostridium cluster). Collins et al. (1994) have previously separated this large group into smaller clusters with three of them corresponding to thermophilic genera (V, Thermoanaerobacter; VI, Moorella; and VII, Thermoanaerobacterium). Of these, cluster VII, Thermoanaerobacterium, appears to be the closest match (relative distance $>11 \cdot 1 \%$ ) as shown in Fig. 3 .

It has been proposed that with bacteria falling within the loosely defined Clostridium cluster, a relative distance of more than $8-10 \%$ constitutes a separate genus, as long as the placement is consistent with physiological data (Engle et al., 1995). Although the organisms described have unique characteristics, such as formate production, absence of spore formation and variable thiosulfate reduction, this is not sufficient for the formation of a new genus. From these results, it is proposed that both isolates be designated members of the genus Thermoanaerobacterium, although their physiological properties warrant an emended genus description. This emendment will effectively eliminate any distinguishing characteristic between the genera Thermoanaerobacter and Thermoanaerobacterium. Clearly, analysis of more isolates representing this new branch (based on 16S rDNA sequence) and an extensive DNA-DNA hybridization study are needed to determine the proper taxonomic relationship amongst this extensive group of thermophiles.

\section{Emendation of the description of the genus Thermoanaerobacterium}

The genus Thermoanaerobacterium has been previously described (Lee et al., 1993b; Liu et al., 1996b). According to the description, members of the genus reduce thiosulfate to elemental sulfur. However, both Thermoanaerobacterium polysaccharolyticum and Thermoanaerobacterium zeae are unable to reduce thiosulfate to elemental sulfur and, therefore, the reduction of thiosulfate to elemental sulfur is not a distinguishing characteristic of the genus Thermoanaerobacterium. This emendment to the genus description also rectifies the placement of Thermoanaerobacterium thermosaccharolyticum, another organism which reduces thiosulfate to sulfide, not elemental sulfur (Collins et al., 1994; McClung, 1935).

\section{Description of Thermoanaerobacterium polysaccharolyticum sp. nov.}

Thermoanaerobacterium polysaccharolyticum (poly. sac.cha.ro.ly'ti.cum. Gr. n. polysacchar many sugars; Gr. adj. lyticus dissolving; N.L. neut. adj. polysaccharolyticum many sugars dissolving).

Cells of Thermoanaerobacterium polysaccharolyticum are straight rods, occurring singly or sometimes in pairs, motile and Gram-positive. Growth occurs under anaerobic conditions. Formation of spores has not been observed. Flagella are present. Anaerobic cultures are catalase-negative and nitrate is not reduced. Indole is not produced. Thiosulfate is reduced to sulfide. Sulfate and sulfur are not reduced. The bacterium exhibits a surface-layer protein. The optimum temperature for growth is $65-68{ }^{\circ} \mathrm{C}$. The maximum temperature at which growth occurs is $70{ }^{\circ} \mathrm{C}$. Growth does not occur at $45^{\circ} \mathrm{C}$. The optimum $\mathrm{pH}$ is $6 \cdot 8-7 \cdot 0$. Doubling times at $68^{\circ} \mathrm{C}$ with glucose, raffinose and melibiose as the carbon source are $2 \cdot 1,3 \cdot 4$ and $5.5 \mathrm{~h}$, respectively. The end products of fermentation on a minimal medium with $0.5 \%(\mathrm{w} / \mathrm{v})$ glucose as the carbon source are ethanol $(30 \mathrm{mM})$, acetate $(20 \mathrm{mM})$, formate $(11 \mathrm{mM})$ and lactate $(5 \mathrm{mM})$. Utilizes glucose, arabinose, galactose, lactose, maltose, mannose, rhamnose, salicin, sucrose, trehalose, xylose, cellobiose, raffinose, melibiose, melizitose and pyruvate. Cellulose, cracked corn, starch, xylan, pectin, sorbose, mannitol, malate, fumarate, citrate, glycerol and $\mathrm{H}_{2} / \mathrm{CO}_{2}$ are not utilized. The $\mathrm{G}+\mathrm{C}$ content is $46 \mathrm{~mol} \%$, as determined by the thermal denaturation method. The type strain of Thermo- 


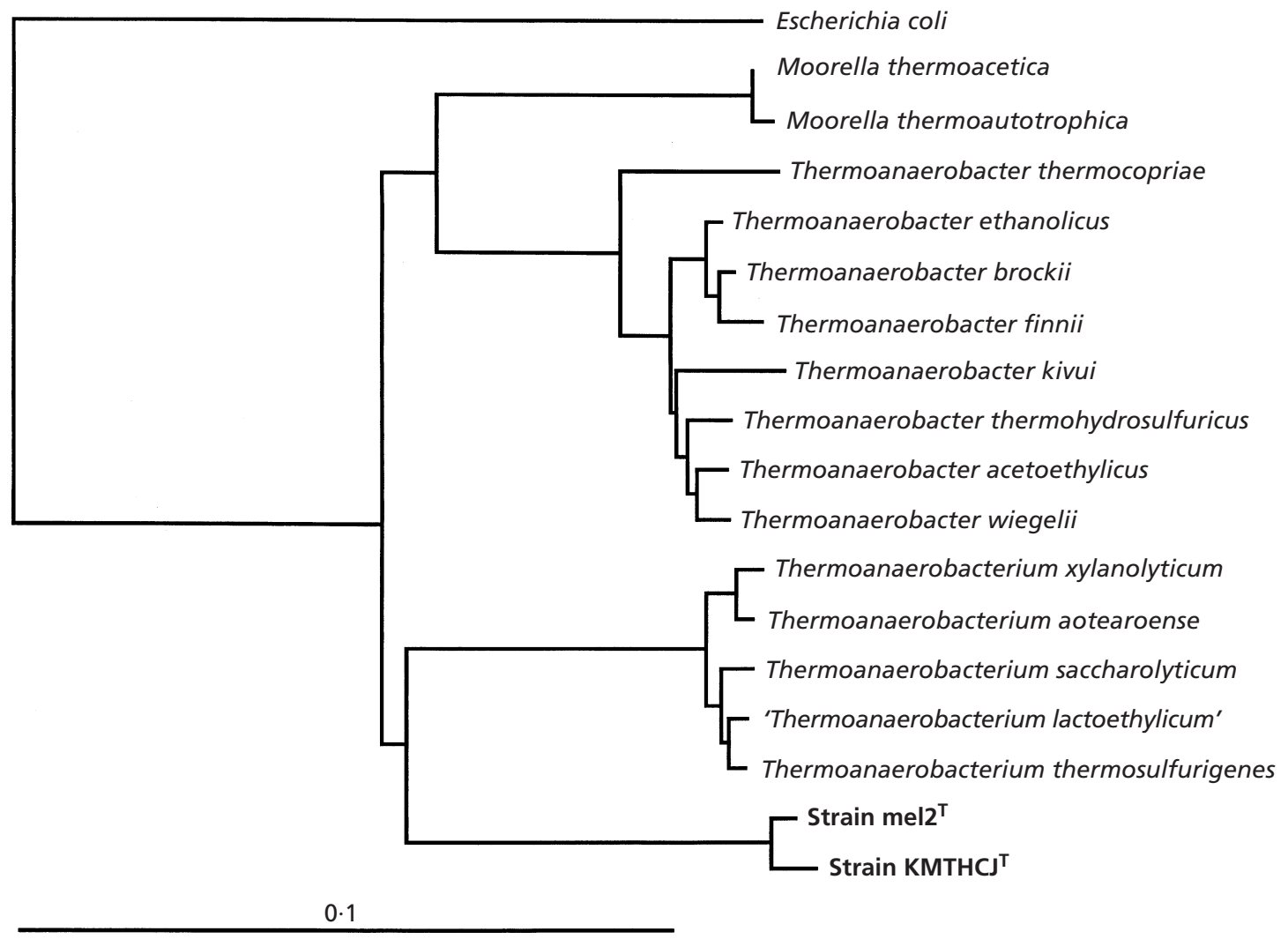

Fig. 3. Phylogenetic dendrogram comparing the $16 \mathrm{~S}$ rRNA gene sequence of strains $K M T H C J^{\top}$ and mel $2^{\top}$ and sequences of the genera Thermoanaerobacter, Thermoanaerobacterium and related genera constructed using the neighbourjoining method. Numbers given at the nodes represent bootstrap values and indicate the percentage probability for the appropriate branches of the tree. Bar, $10 \%$ difference in sequence.

anaerobacterium polysaccharolyticum is strain $\operatorname{KMTHCJ}^{\mathrm{T}}\left(=\right.$ ATCC BAA- $\left.17^{\mathrm{T}}=\operatorname{DSM} 13641^{\mathrm{T}}\right)$.

\section{Description of Thermoanaerobacterium zeae sp. nov.}

Thermoanaerobacterium zeae (ze.ae. Gr. n. zeae of corn, describing the use of corn as a substrate for growth).

Cells are motile, Gram-positive rods and occur singly or sometimes in pairs. Growth occurs under anaerobic conditions. Formation of spores has not been observed. Peritrichous flagella are present. Grows on solid media. Anaerobic cultures are catalase-negative and nitrate is not reduced. Indole is not produced. Thiosulfate, sulfate and sulfur are not reduced.

The optimum temperature is $65-70{ }^{\circ} \mathrm{C}$. The maximum temperature at which growth occurs is $72^{\circ} \mathrm{C}$ and growth does not occur at $37^{\circ} \mathrm{C}$. The $\mathrm{pH}$ range is 3.9-7.9. The fastest doubling time observed for Thermoanaerobacterium zeae grown on glucose in a minimal media is $1.8 \mathrm{~h}$ for the optimum temperature range. Growth is completely inhibited by tetracycline $\left(50 \mu \mathrm{g} \mathrm{ml} \mathrm{m}^{-1}\right)$, rifampicin $\left(50 \mu \mathrm{g} \mathrm{ml} \mathrm{m}^{-1}\right)$, kanamycin $\left(50 \mu \mathrm{g} \mathrm{ml}^{-1}\right)$ and erythromycin $\left(50 \mu \mathrm{g} \mathrm{ml}^{-1}\right)$. Growth occurs in the presence of concentrations of $300 \mathrm{mM}$ $\mathrm{NaCl}, 450 \mathrm{mM} \mathrm{KCl}$ and $150 \mathrm{mM} \mathrm{NH} \mathrm{Nl}_{4}$. The end products of fermentation on a minimal medium with $0.5 \%(\mathrm{w} / \mathrm{v})$ glucose as the carbon source are ethanol $(33 \mathrm{mM})$, formate $(21 \mathrm{mM})$, acetate $(14 \mathrm{mM})$ and lactate $(7 \mathrm{mM})$. Utilizes cracked corn, starch, xylan, glucose, arabinose, galactose, lactose, maltose, mannose, rhamnose, salicin, sucrose, trehalose, xylose, cellobiose, raffinose, melibiose, melizitose and pyruvate. Cellulose, pectin, sorbose, mannitol, malate, fumarate, citrate, glycerol and $\mathrm{H}_{2} / \mathrm{CO}_{2}$ are not utilized. The $\mathrm{G}+\mathrm{C}$ content is $42 \mathrm{~mol} \%$ as determined by the thermal denaturation method. The type strain of Thermoanaerobacterium zeae is strain $\operatorname{mel}^{\mathrm{T}}$ (= ATCC BAA $-16^{\mathrm{T}}=$ DSM $13642^{\mathrm{T}}$ ).

\section{ACKNOWLEDGEMENTS}

We would like to thank the Council for Agricultural Research (CFAR-Illinois), the Illinois Soybean Marketing Board and Illinois Corn Marketing Board for funding. We would also like to thank the following personnel from the University of Illinois at Urbana-Champaign: Donna Hilton from the Department of Animal Sciences for VFA quanti- 
fication, Dr Hans-Peter Blaschek from the Department of Food Science and Human for the utilization of his laboratory's GC for solvent and VFA analysis, Dr Robert Sanford from the Department of Civil and Environmental Engineering for the utilization of his laboratory's HPLC, Dr Joanne Chee-Sanford from the Department of Animal Sciences for HPLC assistance and the staff of the Center for Microscopy \& Imaging from the Department of Veterinary Biosciences for the electron microscopy. Finally, a special thanks to Mike Cotta, Terry Whitehead and Rhonda Zeltwanger of the US Department of Agriculture, Agriculture Research Service, National Center for Agricultural Utilization Center in Peoria, IL, for $\mathrm{G}+\mathrm{C}$ content determination.

\section{REFERENCES}

Brechtel, E. \& Bahl, H. (1999). In Thermoanaerobacterium thermosulfurigenes EM1 S-layer homology domains do not attach to peptidoglycan. J Bacteriol 181, 5017-5023.

Birnboim, H. C. \& Doly, J. (1979). A rapid extraction procedure for screening recombinant plasmid DNA. Nucleic Acids Res 7, $1513-1523$.

Cann, I. K. O., Kocherginskaya, S., King, M. R., White, B. A. \& Mackie, R. I. (1999). Molecular cloning, sequencing and expression of a novel multidomain mannanase gene from Thermoanaerobacterium polysaccharolyticum. J Bacteriol 181, 1643-1651.

Carreira, L. H., Wiegel, H. J. \& Ljungdahl, L. G. (1983). Production of ethanol from biopolymers by anaerobic, thermophilic, and extreme thermophilic bacteria. I. Regulation of carbohydrate utilization in mutants of Thermoanaerobacter ethanolicus. Biotechnol Bioeng Symp 13, 183-191.

Cato, E. P. \& Stackebrandt, E. (1989). Taxonomy and phylogeny. In Clostridia, pp. 1-26. Edited by N. P. Minton \& D. J. Clark. New York: Plenum.

Cayol, J.-L., Ollivier, B., Patel, B. K. C., Ravot, G., Magot, M., Ageron, E., Grimont, P. A. D. \& Garcia, J.-L. (1995). Description of Thermoanaerobacter brockii subsp. lactiethylicus subsp. nov., isolated from a deep subsurface French oil well, a proposal to reclassify Thermoanaerobacter finnii as Thermoanaerobacter brockii subsp. finnii comb. nov., and an emended description of Thermoanaerobacter brockii. Int J Syst Bacteriol 45, 783-789.

Collins, M. D., Lawson, P. A., Willems, A., Cordoba, J. J., Fernandez-Garayzabal, J., Garcia, P., Cai, J. \& Farrow, J. A. E. (1994). The phylogeny of the genus Clostridium: proposal of five new genera and eleven new species. Int $J$ Syst Bacteriol 44, 812-826.

Cook, G. M., Rainey, F. A., Patel, B. K. C. \& Morgan, H. W. (1996). Characterization of a new obligately anaerobic thermophile, Thermoanaerobacter wiegelii sp. nov. Int J Syst Bacteriol 46, 123-127.

Engle, M., Li, Y., Woese, C. \& Wiegel, J. (1995). Isolation and characterization of a novel alkalitolerant thermophile, Anaerobranca horikoshii gen. nov., sp. nov. Int J Syst Bacteriol 45, 454-461.

Engle, M., Li, Y., Rainey, F., DeBlois, S., Volker, M., Reichert, A., Mayer, F., Messner, P. \& Wiegel, J. (1996). Thermobrachium celere gen. nov., sp. nov., a rapidly growing thermophilic, alkalitolerant, and proteolytic obligate anaerobe. Int J Syst Bacteriol 46, 1025-1033.

Felsenstein, J. (1995). PHYLIP - Phylogeny Inference Package (version 3.2). Cladistics 5, 164-166.

Fiala, G. \& Stetter, K. O. (1986). Pyrococcus furiosus sp. nov. represents a novel genus of marine heterotrophic archaebacteria growing optimally at $100^{\circ} \mathrm{C}$. Arch Microbiol 145, 56-61.

Freier, D., Mothershed, C. P. \& Wiegel, J. (1988). Characterization of Clostridium thermocellum JW20. Appl Environ Microbiol 54, 204-211.

Higgins, D. G., Bleasby, A. J. \& Fuchs, R. (1991). CLUSTAL V: improved software for multiple sequence alignment. Comput Appl Biosci 8, 189-191.

Holt, J. G., Krieg, N. R., Sneath, P. H. A., Staley, J. T. \& Williams, S. T. (1994). Irregular, nonsporing Gram-positive rods. In Bergey's Manual of Determinative Bacteriology, 9th edn. pp. 571-596. Baltimore: Williams \& Wilkins.

Jones, W. J., Leigh, J. A., Mayer, F., Woese, C. R. \& Wolfe, R. S. (1983). Methanococcus jannaschii sp. nov., an extremely thermophilic methanogen from a submarine hydrothermal vent. Arch Microbiol 136, 254-261.

Jukes, T. H. \& Cantor, C. R. (1969). Evolution of protein molecules. In Mammalian Protein Metabolism, vol. 3, pp. 21-132. Edited by H. M. Munro. New York: Academic Press.

Lee, Y.-E., Lowe, S. E., Henrissat, B. \& Zeikus, J. G. (1993a). Characterization of the active site and thermostability regions of endoxylanase from Thermoanaerobacterium saccharolyticum B6A-RI. J Bacteriol 175, 5890-5898.

Lee, Y.-E., Jain, M. K., Lee, C., Lowe, S. E. \& Zeikus, J. G. (1993b). Taxonomic distinction of saccharolytic thermophilic anaerobes: description of Thermoanaerobacterium xylanolyticum gen. nov., sp. nov., and Thermoanaerobacterium saccharolyticum gen. nov., sp. nov.; reclassification of Thermoanaerobium brockii, Clostridium thermohydrosulfuricum E100-69 as Thermoanaerobacter brockii comb. nov., Thermoanaerobacterium thermosulfurigenes comb. nov., and Thermoanaerobacter thermohydrosulfuricus comb. nov., respectively; and transfer of Clostridium thermohydrosulfuricum 39E to Thermoanaerobacter ethanolicus. Int J Syst Bacteriol 43, 41-51.

Liu, S.-Y., Gherardini, F. C., Matuschek, M., Bahl, H. \& Wiegel, J. (1996a). Cloning, sequencing and expression of the gene encoding a large S-layer-associated endoglucanase from Thermoanaerobacterium sp. strain JW/SL-YS 485 in Escherichia coli. $J$ Bacteriol 178, 1539-1547.

Liu, S.-Y., Rainey, F. A., Morgan, H. W., Mayer, F. \& Wiegel, J. (1996b). Thermoanaerobacterium aotearoense sp. nov., a slightly acidophilic, anaerobic thermophile isolated from various hot springs in New Zealand, and emendation of the Thermoanaerobacterium. Int J Syst Bacteriol 46, 388-396.

McClung, L. S. (1935). Studies on anaerobic bacteria; IV. Taxonomy of cultures of a thermophilic species causing 'swells' of canned foods. J Bacteriol 29, 189-203.

Marmur, J. \& Doty, P. (1962). Determination of the base composition of deoxyribonucleic acid from its thermal denaturation temperature. J Mol Biol 5, 109-118.

Murray, R. G. E., Doetsch, R. N. \& Robinow, C. F. (1994). Determinative and cytological light microscopy. In Methods of General and Molecular Biology, pp. 21-41. Edited by P. Gerhardt, R. G. E. Murray, W. A. Wood \& N. R. Krieg. Washington, DC: American Society for Microbiology.

Schink, B. \& Zeikus, J. G. (1983). Clostridium thermohydrosulfurigenes sp. nov., a new thermophile that produces elemental sulfur from thiosulfate. J Gen Microbiol 129, 1149-1158.

Smibert, R. M. \& Krieg, N. R. (1994). Phenotypic characterization. In Methods for General and Molecular Bacteriology, pp. 607-654. Edited by P. Gerhardt, R. G. E. Murray, W. A. Wood 
\& N. R. Krieg. Washington, DC: American Society for Microbiology.

Wiegel, J. \& Ljungdahl, L. G. (1981). Thermoanaerobacter ethanolicus gen. nov., sp. nov., a new extreme thermophilic, anaerobic bacterium. Arch Microbiol 128, 343-348.

Winker, S. \& Woese, C. R. (1991). A definition of the domains
Archaea, Bacteria and Eucarya in terms of small subunit ribosomal characteristics. Syst Appl Microbiol 13, 161-165.

Yamamoto, K., Murakami, R. \& Takumura, Y. (1998). Isoprenoid quinone, cellular fatty acid composition and diaminopimelic acid isomers of newly classified thermophilic anaerobic Grampositive bacteria. FEMS Microbiol Lett 161, 351-358. 